\title{
Single Parenting as Correlate of Academic Performance of Students in Unity Secondary School in South East Geo-Political Zone in Nigeria
}

\author{
Christiana Ijeoma Anyakoha \\ Department of Educational Foundations and Administration \\ Alvan Ikoku University of Education, Faculty of Education, Owerri
}

\begin{abstract}
The study examined Single parenting as correlate of academic performance of students in unity schools in South East Geo-political zone of Nigeria, it is a correlational survey. The population was 476 (212 males and 264 female) senior secondary school students in the twelve (12) unity secondary schools in South East Geopolitical zones of Nigeria which formed the sample size, classroom Academic Performance Scores, Single Parenting and Academic performance of students Questionnaire (SPAPSQ) were the instruments used for data evaluation. Two research questions were asked to guide the study and two null hypotheses were formulated and were tested at 0.05 level of significance. The reliability indexes of the instruments were 0.81 and 0.77 respectively using Pearson " $r$ " formula. Mean score, z-test and Pearson product moment correlation coefficient statistic were employed for data analysis. It was found out among others that despite the financial status of single parent, they support and assist their children educationally, the study also reveals that male and female students of single parenthood did not differ in terms of influence of 5educational status on their academic performance. Based on these findings, it is recommended among others that, school counselors, sociologists of education and psychologists should assist students to improve more on their academic performance, effort should be made to find out the type of homes the children come from. The counselors should counsel the parents of students especially those from single-parent homes.
\end{abstract}

\section{Introduction}

One widely held aim of education is to equip students with the knowledge, skills, attitude and competencies that enable them to render useful services to themselves and to the society. Education is, viewed as an indispensable catalyst that strongly influences the development and economic fortunes of a nation and the quality of life of its people.

According to Asiabaka [1], education is the key to national development, it provides the intellectual capability needed by man to harness the human and material resources for scientific and technological advancement. Furthermore, it is an instrument for the

realization of a nation's growth and development, because the level of a nation's literacy determines her extent of development.

Secondary education occupies a very unique position in the educational system of Nigeria, because it is that level that determines the academic and professional career of students. Over the years, the investigations of the factors that influence academic performance of students have attracted the interest and concern of teachers, counsellors, sociologists, psychologists, researchers and school administrators in Nigeria.

Definitely, different factors are capable of influencing the academic performance of secondary school students, such factors may be the students intrinsic attributes (intelligence, state of health, motivation, anxiety etc) and their environmental attributes (availability of suitable learning environment, adequacy of educational infrastructure, like textbooks and well-equipped laboratories)

The home has a great influence on the students' psychological, emotional, social and economic state. the state of the home affects the individual since the parents are the first socializing agents in an individual's life.

This is because the family background and context of a child can affect the child's reaction to life situations, this could have subsequent effect on the child's level of performance.

Although, the school is responsible for the experiences that makes up the individual's life during school periods, yet parents and the individuals experiences at home play tremendous role in building the personality of the child and making the child what he or she is.

The foundation of what a person becomes in the society is laid in the home at the initial stage of life.

Parents, therefore, have important roles to play in seeing to it that the youths acquire the appropriate social, psychological, moral and academic development.

In Nigeria, among the lgbo's, (eastern part of Nigeria) the parental role are culturally determined. Maternal role is that of childcare and home making while the paternal role is that of economic responsibilities and discipline of children. 
Generally, it is the responsibilities of the family to train and bring up the child in the norms and values of the society.

Divorce and separation of various kinds of death of one spouse, however may leave the roles in the hands of a single parent.

Single parenting can be defined as a situation in which one of the two individuals involved in the conception of a child is being responsible for upbringing of the child.

Single parenthood may also arise when either the male or female decides to produce and rear a child or children outside wedlock.

In Nigeria, the existence of single parents was formerly unknown and where they existed they are ignored as exceptional cases of moral aberration. In the case of death of one's spouse, he or she is advices and also expected to remarry and the children will be trained by the relations of both the man and woman that is why Chinua Achebe said "it takes a community to train a child in Africa".

In the present dispensation, however, they are fast growing family patterns both inside and outside Nigeria. Although there are no available statistics of single-parent families in Nigeria, practical experience and newspaper reports show that there is an increase in the number of single parents in Nigeria.

The literature is replete with the negative effects of single parenting on the child and the society. Johnson in Ortesse [7] found that most medical students whose fathers have been absent while they were aged one to five years were more psychopathic and criminal in behaviour than those whose fathers were not absent during this period.

The child is morally upright and emotionally stable when the caring responsibilities are carried out by both parents. The family has a great influence on the child's physical, mental and moral development.

Single parenting has been found to be one of the major causes of the failure recorded by students at the senior secondary school level. This is because both parents have roles to play in the training and development of the child, when such roles of training and developing the child do not complement each other, it might affect the cognitive development of the child as he or she grows.

Single parents who are illiterates have the problem of lack of knowledge to guide their children towards making decisions as regards to the choice of subjects that are consistent with their abilities and passion. These and others go a long way to influence the academic performance of the children.

Another significant problem of single parenting that affects the academic performance of adolescents is poverty, most single parents are poor financially hence they find it difficult to provide the needed materials, balanced meal and quality health care that are necessary for improved academic performance of their children. In extreme cases, the poverty can move students towards some negative behaviours like prostitution, cybercrime, armed robbery, kidnapping and others, thereby reducing the time they devote to their studies and these affect their academic performance negatively. What then is the influence of single parenting on the academic performance of students in unity secondary schools in south east Nigeria in view of the myriads of difficulties such children seem to face?

\section{Theoretical Framework}

There have been numerous theoretical contributions to our understanding of family. This study is theoretically framed on Joyce Epstein's school-family-community partnership model, theory of family deflect model and risk and protective factor model.

In this model, research recognizes parent involvement as an important factor in the quality of a child's education. Joyce Epstein's school - family community partnership model is an influential model in parent involvement research. The model redefines the relationship between schools, families and communities as one of overlapping spheres of influence that share a concern about the success of the child. As a framework for increasing parental participation in Education, the model recognizes six types of educational involvement and encourages schools to develop activities that engage schools. Families and communities within the six types of model has been influential in shaping social policy regarding parent's involvement in education.

Epstein's six types of involvement

- Parenting

- Communicating

- Volunteering

- Learning at home

- Decision making

- Collaborating with community.

Theory of Family Deficit Model

This study anchors family on the theory of Family Deficit Model in Donahoo [3], which sees nuclear or two parent family as the ideal family structure and single parent families as deviant from the ideal family.

Risk and Protective Factor Model

Developed in the early 1990s, the Risk and Protective Factor Model does not regard single parent families as irregular because the foundation for the model is that all families have both strengths and weakness. The implication of these theories to the present study lies on the fact that students' performance in school is mediated by their upbringing which perhaps is influential by their family background. 


\section{Research Questions}

The following research questions were asked to guide the study:

- What is the relationship between educational status of single parents on the academic performance of senior secondary $1-3$ students

- What is the relationship between financial status of single parents on the academic performance of senior secondary $1-3$ students

\section{Hypotheses}

The following null hypotheses were formulated and were tested at 0.05 level of significance

- There is no significant relationship between the mean responses on the influence of educational status of single parents on their academic performance.

- There is no significant relationship between the mean response score of male and female students on the influence of financial status of single parents on their academic performance.

\section{Methodology}

This study is a survey research which adopted a correlation survey, in order to correlate the influence of single parenting on the academic performance of students. Population for the study comprises of 476 Senior Secondary School Students in the 12 unity secondary schools in south east Geo-political zone of Nigeria. The researcher utilized the whole population of 476 students as the sample size (212 males and 264 females) using purposive sampling technique. To execute the study, two instruments were used; Classroom Academic Performance Scores, and Single Parenting and Academic Performance of Students Questionnaire (SPAPSQ), the Classroom Academic Performance Scores were drawn from the performance of the students in English and Mathematics for 2012/2013 session with grading of A, C, P and F, since English Language and Mathematics were the only subjects common to all students from various background.

Single parenting and Academic Performance of Students Questionnaire (SPAPSQ) contained 30 items, also structured along the rating scale of Strongly Agree, Agree, Disagree and Strongly Disagree, having the points of 4, 3, 2" and 1 respectively, the collected data were analyzed using mean scores for the research question, for testing of hypothesis, z-test was used to test hypotheses one and two, at 0.05 level of significance.

This study was carried out in unity secondary schools in south-east geo-political zone of Nigeria, the south east geo-political zone of Nigeria is made up of five (5) states. The population for the study comprised of 476 (212 male and 264 females) senior secondary school students in the 12 unity secondary schools in south-east geo-political zone in Nigeria.

Table 1. Population Distribution of the Senior Secondary Students from single parenthood

\begin{tabular}{|l|l|l|l|}
\hline $\begin{array}{l}\text { S/ } \\
\text { N }\end{array}$ & Name of Unity Schools & $\begin{array}{l}\text { No. of Male } \\
\text { Students } \\
\text { from Single } \\
\text { Parents }\end{array}$ & $\begin{array}{l}\text { No. of } \\
\text { Female } \\
\text { Students } \\
\text { from } \\
\text { Single } \\
\text { Parents }\end{array}$ \\
\hline 1 & FGC, ENUGU & 13 & 29 \\
\hline 2 & FGGC, LEJJA, ENUGU & 21 & 30 \\
\hline 3 & FGC, NISE, ANAMBRA & 25 & 22 \\
\hline 4 & $\begin{array}{l}\text { FGGC, } \\
\text { ANAMBRA ONITSHA, }\end{array}$ & 18 & 19 \\
\hline 5 & FSTC, AWKA, ANAMBRA & 20 & 42 \\
\hline 6 & FGC, OHAFIA, ABIA & 5 & 9 \\
\hline 7 & FGGC, UMUAHIA, ABIA & 27 & 29 \\
\hline 8 & FSTC, OHANSO, ABIA & 23 & 18 \\
\hline 9 & FGC, OKPOSI, EBONYI & 13 & 18 \\
\hline 10 & $\begin{array}{l}\text { FGGC, } \text { EZAMGBO, } \\
\text { EBONYI }\end{array}$ & 8 & 9 \\
\hline 11 & FGC, OKIGWE, IMO & 15 & 21 \\
\hline 12 & FGGC, OWERRI, IMO & 24 & 18 \\
\hline & Total & 212 & 264 \\
\hline
\end{tabular}

(Source: Imo State Education Management Board/various schools counselor's records, 2013)

Purposive sampling techniques were employed because the sample must be made of students from single parent families. The purposive sampling technique therefore allowed the researcher to sample only students of this characteristic for the study, the whole population of (476) students found to be from single parent family across the 12 unity schools in the zone were used for the study.

The researcher adopted a test-retest method to determine the reliability of the items in each of the research instruments, 40 copies of the instrument were administered to respondents outside the sample group and the scores were collected. The same instruments were re-administered on the same group at an interval of two weeks and the scores were collected too, the two sets of scores were correlated separately using Pearson Product Moment Correlation Statistics; the calculation of the reliability produced a reliability coefficient of 0.81 and 0.77 , these indicates that the instruments are reliable.

Since the questionnaire was based on simple normal rating scale, sample frequency count and mean scores was used in answering the research questions. On the other hand, z-test was used to test hypotheses one and two since the sample size is more than 30 . 
Table 2. Summary of z-test Analysis of the Mean Response Scores of Male and Female Students on the Influence of Educational Status of Single Parents on their Academic Performance

Table 3. Summary of z-test analysis of the Mean Response Scores of Male and Female Students on the Influence of Financial Status of Single Parents on their Academic Performance

\begin{tabular}{|l|l|l|l|l|l|l|l|}
\hline Respondents & $\mathbf{n}$ & $\mathbf{x}$ & $\mathbf{s d}$ & $\mathbf{d f}$ & $\mathbf{Z}_{\text {eal }}$ & $\mathbf{Z}_{\text {crt }}$ & Decision \\
\hline Male Students & 212 & 2.53 & 0.49 & 474 & 0.01 & 1.96 & Accept $\mathrm{H}_{0}$ \\
Female Students & 264 & 2.52 & 0.49 & & & & \\
& & & & & & & \\
\hline
\end{tabular}

Table 2 also indicated that the $\mathrm{z}$-calculated value of 0.01 is less than the z-tabulated value of

report of Joyce Epstein - which recognizes parent's

\begin{tabular}{|l|cc|c|c|c|c|c|c|}
\hline Respondents & \multicolumn{1}{c|}{$\mathbf{n}$} & $\mathbf{x}$ & $\mathbf{s d}$ & $\mathbf{d f}$ & $\mathbf{Z}_{\text {eal }}$ & $\mathbf{Z}_{\text {crti }}$ & Decision \\
\hline Male Students & & 21 & 2.47 & 0.567 & 474 & 0.47 & 1.96 & ${\text { Accept } \mathrm{H}_{0}}^{\text {Female }}$ \\
$\begin{array}{l}\text { Students } \\
\text { 2 }\end{array}$ & 26 & 2.59 & 0.587 & & & & \\
\hline
\end{tabular}

1.96 at 0.05 level of significance with degree of freedom (df) of 474. The null hypotheses is retained which indicated that there is no significant relationship between the mean response scores of male and female students on the influence of educational status of single parents on their academic performance.

Table 3 also indicated that the $\mathrm{z}$-calculated value of 0.47 is less than the z-tabulated value of 1.96 at 0.05 level of significance with degree of freedom (df) of 474. The null hypotheses is retained which indicated that there is no significant relationship between the mean response scores of male and female students on the influence of financial status of single parents on their academic performance.

\section{Discussion of Findings}

Table 2 reveals that single parents who are educated assist their children in their academic endeavors, the study revealed that single parents who are educated assist their children in their academic endeavors this finding is buttressed by the fact that student's parenthood and family background have attracted a lot of researchers since the shocking Coleman report (1966) which related the influence of the home on school performance significantly higher than that of the school itself according to study, the most important factors in school performance are the educational and social background of the child's family and socio-economic background of the other children in the school. The findings of Coleman report were further reiterated by the Plowder [8] report in Great Britain which also concluded that family background was more important than school factors in determining children's educational performance and the involvement as an important factor in the quality of a child's education.

Table 3 reveals that despite the financial status of single parents, they assist \& support their children's education. The findings of this study agree with the findings of Nwachukwu [6] who found out that despite the low income of single parent, their children make effort to excel in their academic endeavour as the parents assist them in the best way they can, in contrast to this finding. Deslandes, Royer and Tincotte [2] revealed that family income can influence parents support and involvement in education and school performance. Although economic pressures often limit or prevent parent involvement in single parent families when single parents make the effort to support their children's education their effort acts as a protective factor. The findings further established that male and female students of single parents did not differ in financial status of their parents.

\section{Conclusion}

This study examined the influence of single parenting on the academic performance of students in unity secondary schools in south-east Nigeria. In order to improve students irrespective of their family structure it was found out among others that single parents who are educated assist their children in their academic endeavors. Despite the financial status of single parent they assist and support their children's education.

\section{Recommendations}

Based on the findings of this study, the following recommendations were made: 
- School counselors/psychologists should assist students with poor academic performance and efforts should be made to identify the type of home the students come from and as much as it is possible the counselor needs to counsel the parents of such students if it is found that such students are from single parent's homes.

- All hands must be on deck in ensuring that appropriate counseling programmes such as group counseling, family counseling, home visits and supportive associations are designed to help children from singleparents and their parents so as to improve the children's academic performance at school.

- Governments, private organizations and individuals concerned with the business of education should endeavor to address the obstacles hindering effective academic performance of students. This can be done by developing achievement motivation in students through achievement motivation training.

- There is also need to keep enlightening the parents of the importance of the home structure on the life of children. This is necessary so that parents can understand the implications and consequences of parental separation and thus mobilize all resources to curtail the problems arising from the situation.

\section{References}

[1] Asiabaka, L P., (2010). Perceptions or Imo State Primary School Teachers of the Primary School Component of the Universal.

[2] Deslandes, R, Royer, E. \& Tincotte D., (1997). School achievement at the secondary level: Influence of parenting style and parent involvement in schooling. McGill journal of education, $32191-207$.

[3] Donahoo, S., (2003) Single Parenting and children's Academic achievement.http://npin.

Org/pnews/2003/pnews303/int303a.htm

[4] Downey, D., (1994). The school performance of children from single-mother and single-father families: Economic or interpersonal deprivation? Journal of Family Issues, 15,129-147.

[5] Epstein, J., (2001) School, family and community partnerships. Boulder, West view Press.

[6] Nwachukwu, F. J., (2011). Single-Parent Family - An Emerging Family Pattern in Nigeria. The Counsellor, 16 (1): $137-146$.

[7] Ortese, P. T., (1998). Single-Parenting in Nigeria;
Counselling Concerns and Implications. The Counsellor, 16(1): 61 - 66 .

[8] Plowder N. C., (1971). Relations of Parenting styles and parental involvement with ninth-grade students achievement. Journal of Early Adolescence, 14, 250 - 267. 